\title{
RELATIONSHIP BETWEEN CLINICOPATOLOGICAL DATA WITH BASAL CELL CARCINOMA HISTOPATHOLOGY SUBTYPES
}

\author{
$\underline{\text { Harry Sundoro }^{1}}$, T. Ibnu Alferraly ${ }^{1}$, Delyuzar $^{1}$, Soekimin ${ }^{1}$, Joko S Lukito ${ }^{1}$, \\ Lidya Imelda Laksmi ${ }^{1}$ \\ Email address: harrysundoro1@gmail.com \\ ${ }^{1}$ Department of Anatomical Pathology, Faculty of Medicine, Universitas Sumatera Utara, Medan, Indonesia
}

Abstract

Background: Basal cell carcinoma $(\mathrm{BCC})$ is an epithelial malignancy most commonly found in human about $75-80 \%$ of non-melanoma cancer. At the moment, BCC has been one of the most important health problems, due to increasing number of incidents. Studies about the relationship between clinicopathologic data and histopathologic subtypes of BCC in Indonesia especially in Medan are still limited. Therefore, the researchers are interested in this study.

Objective: To analyze the relationship between clinicopathologic data and histopathologic subtypes of BCC.

Methods: A cross-sectional study was performed using formalin-fixed tissue paraffin blocks from 38 BCC patients. Clinical data such as age, gender, occupation, ethnic groups, tumour location and size were recorded. Then, each BCC cases were reviewed for determining histopathologic subtypes of BCC. Then, the relationship between clinicopathologic data and histopathologic subtypes in BCC was assassed and analyzed with statistical software by using the chi-square test or fisher exact test.

Results and Discussion: About $68.4 \%$ samples aged $>60$ years old; $57.9 \%$ women; $36.8 \%$ housewives; $44.7 \%$ located in mid face, mostly in palpebra; $50 \%$ with size of $\geq 1.5 \mathrm{~cm}$; $78.9 \%$ nodular BCC; and $89.5 \%$ with lower recurrence risks. Men tend to have $\mathrm{BCC}$ than women because they smoke more and tend to work outdoor. That's why they are more exposed to UV rays. These factors are thought to trigger tumour growth.

Conclussion: There were no statistically significant relationships between age, gender, occupations, ethnic, tumour location and size with histopathologic subtypes of BCC

Keywords: BCC, clinicopathology, histopathologic subtypes

\section{Introduction}

Skin is the outermost organ that protects the human body from the surrounding environment. In general, skin cancer is divided into melanoma and non-melanoma. Non-melanoma skin cancers include basal cell carcinoma (BCC) and squamous cell carcinoma.1 BCC is the most common epithelial malignancy in humans, accounting for 75-80\% of non-melanoma cancers.1-6 Currently, BCC is one of health problem of considerable importance, with increasing incidence. 7,8 Incidence rates are known to be inversely related to geographic latitude and higherin fairskinned populations.

Worldwide, the incidence of $\mathrm{BCC}$ is increasing everywhere but Australia, where it appears to have remained stable. 2 The incidence of BCC is known to reach 2.75 million cases worldwide annually.7 In the United States, the incidence rate is about 576 cases per 100,000 person-years. .2 The incidence of BCC in Asia is still low, namely in Japan $(0.131 \%)$, Korea $(0.048 \%)$, and Taiwan $(0.015 \%) .10$ In Indonesia alone, the incidence of this skin cancer in 2010 reached 1,429 cases. 7

BCC often occurs in the elderly, aged between 50-80 years, with a mean of about 65 years.1,4,11,12 The incidence of this carcinoma will increase significantly with increasing age.2,11 This increase in incidence is greatest significantly found in young women in Europe (Netherlands and Denmark) and the United States with the ratio of women more than men compared to the older population (where there are more men than women). The difference in this ratio occurs due to the high use of tanning beds by young women (tanning baths are a tool to get a brown skin color by involving a device that emits ultraviolet radiation).9,12 The ratio of males to females affected is usually around $1.5-2: 1.2,12$

Exposure to ultraviolet (UV) light is a major risk factor for BCC.13 The risk of disease increases with periods of intermittent sun exposure. In addition, other risk factors include ionizing radiation, arsenic exposure, inherited 
disease syndromes, and immunosuppression.14 A high predilection for BCC occurs in the head or neck (52\%), trunk (27\%), arms or upper limbs (13\%) and lower limbs (8\%). If based on the calculated body surface area, the highest number was found in men and women, namely on the face, especially the eyelids, lips and nasolabial folds, followed by ears, nose and cheeks. Even so, these lesions can also appear on the neck, back and shoulders and the neck, shoulders and outer arms.1,3 Apart from clinical manifestations, additional investigations are neededto assist in making the diagnosis, such as histopathological examination.13 3

Histopathological examination is the gold standard examination in the enforcement of BCC. Histopathological diagnosis and classification of $\mathrm{BCC}$ are important in determining patient treatment.16,17

WHO in 2017 divided BCC into subtypes BCC NOS, Nodular BCC, Superficial BCC, Micronodular BCC, Infiltrating BCC, Sclerosing/morphoeic BCC, Basosquamous carcinoma, Pigmented BCC, BCC with sarcomatoid differentiated, BCC with adnexal differentiated, and Fibroepithelial BCC. Different BCCs are associated with a low or high risk of recurrence and are factors that determine the patient's prognosis.16 Poor prognostic factors include tumor size $>2 \mathrm{~cm}$, depth of invasion, mid-face area, poorly demarcated margins, and immunosuppression.14 In addition, other important factors include the size of the lesion and the extent of the surgery being tumor-free or not.16

Clinical pathology was documented as age, gender, occupation, ethnicity, tumor location, and tumor size. The most widely used histological classifications are growth and differentiation patterns foot of the column.

\section{Material and Methods}

This study is an analytic study that aims to determine the relationship between clinicopathological data and BCC histopathological subtypes with a cross sectional approach where each sample in this study was only observed once and at a time. The samples in this study were all paraffin slides or blocks that were diagnosed histopathologically as BCC in the skin and met the inclusion and exclusion criteria at the Anatomic Pathology Unit at $\mathrm{H}$. Adam Malik Hospital Medan. The sample was selected using a consecutive sampling technique. This research was conducted after obtaining approval from the Health Research Ethics Commission, Faculty of Medicine, University of North Sumatra with No: 712/KEP/USU/2021. This study aims to determine the relationship between clinicopathological data and BCC histopathological subtypes at the Anatomic Pathology Unit at H. Adam Malik Hospital Medan in 2018-2020. There have been 38 research samples that meet the inclusion criteria and exclusion criteria.

In this study, the characteristics of BCC samples were assessed based on age, gender, occupation, ethnicity, tumor location, tumor size, and histopathological diagnosis.

The data obtained in this study will be processed computerized with the help of the statistical package for the social sciences (SPSS22) version software (SPSS Inc., Chicago), and the results will be presented in tabular form. If the data is in the form of categorical and categorical, then analysis test is performed by using the Chi Square test and Fisher exact test. If the data is in the form of categorical and numeric, then the analysis test is carried out using an independent $\mathrm{T}$ test.

\section{Results}

There have been 38 research samples that meet the inclusion criteria and exclusion criteria. In this study, the characteristics of BCC samples were assessed based on age, gender, occupation, ethnicity, tumor location, tumor size, and histopathological diagnosis (Table 4.1).

Table 1. Characteristics of basal cell carcinoma samples

\begin{tabular}{|c|c|c|}
\hline characteristics & Total ((n) & Percentage (\%) \\
\hline \multicolumn{3}{|l|}{ Age (years) } \\
\hline$<20$ years & - & - \\
\hline $21-40$ years & 1 & 2,6 \\
\hline $41-60$ years & 11 & 28,9 \\
\hline$>60$ years & 26 & 68,4 \\
\hline \multicolumn{3}{|l|}{ Gender } \\
\hline Female & 22 & 57,9 \\
\hline Male & 16 & 42,1 \\
\hline \multicolumn{3}{|l|}{ Work } \\
\hline Housewife & 14 & 36,8 \\
\hline Farmer & 9 & 23,7 \\
\hline private employees & 12 & 31,6 \\
\hline retired & 3 & 7,9 \\
\hline
\end{tabular}




$\begin{array}{lcc}\text { Ethnic group } & & 7,9 \\ \text { Aceh } & 3 & 21,1 \\ \text { Batak } & 8 & 18,4 \\ \text { Java } & 7 & 34,2 \\ \text { Karo } & 13 & 10,5 \\ \text { Melayu } & 4 & 2,6 \\ \text { Nias } & 1 & 5,3\end{array}$

Tumor location

Upper face

Frontal

Mid face

Nose

Eye

Periorbita

Palpebra

Ear

cheek

Lower face

Lip

Face location unknown

Neck and other locations

Tumor Size

$<0,5 \mathrm{~cm}$

$0,5-0,99 \mathrm{~cm}$

$1-1,49 \mathrm{~cm}$

$\geq 1,5 \mathrm{~cm}$

Diagnosis

Nodular BCC

Superficial BCC

Pigmented BCC

Infundibulocystic BCC

Fibroepithelial BCC

Basosquamous BCC

Sclerosing/ morphoeic BCC

Infiltrating BCC

BCC dengan diferensiasi sarkomatoid

Micronodular BCC

Risk of recurrence

Lower risk BCC

$\begin{array}{cc}3 & 7,9 \\ 5 & 13,2 \\ 11 & 28,9 \\ 19 & 50\end{array}$

$30 \quad 78,9$

$3 \quad 7,9$

12,6

-

-

Based on Table 1, the characteristics of the BCC sample shows that the mean and standard deviation of the BCC sample is $64.24 \pm 10.218$ years (range 35-83 years). In addition, it is also known that most of the samples are $>60$ years old, that is as many as 26 people $(68.4 \%)$. The second largest age group was 41-60 years (11 people, $28.9 \%$ ), followed by 1 person aged $21-40$ years $(2.6 \%)$. There is no sample aged $<20$ years. Of the 38 samples, most of the samples were female, as many as 22 people $(57.9 \%)$. While the rest, 16 people are male $(42.1 \%)$.

Based on occupation, from 38 samples, most of the samples were housewives, as many as 14 people (36.8\%). There are as many as 12 samples are private employees (31.6\%), 9 farmers (23.7\%), and 3 retirees (7.9\%). Based on ethnicity, most of the samples were Karo (13 people, 34.2\%), followed by 8 Batak (21.1\%), 7 Javanese (18.4\%), 4 Melayu (10.5\%), 3 Aceh (7.9\%), 2 South Tapanuli (5.3\%) and 1 Nias (2.6\%).

In addition, based on the location of the tumor in this study, tumors on the face were divided into 3 , namely the upper face, mid face, and lower face. Among these three locations, most of the carcinomas were found in the 
mid face (17 people, 44.7\%), which consisted of 6 eyelids (15.8\%), 4 eyes (10.5\%), 3 nose (7.9\%), 2 cheeks $(5.3 \%), 1$ periorbit $(2.6 \%)$, and 1 ear $(2.6 \%)$. There were 2 samples had carcinoma on the upper face $(5.3 \%)$ and only 1 in the lower face (lips) (2.6\%). There were 14 samples (36.8\%) which were found in the facial area, but their location was not clearly known. Apart from the facial area, BCC samples could be found in other areas such as the neck (4 persons, $10.6 \%$ ).

Based on tumor size, the mean and standard deviation of the sample had a size of $1.789 \pm 1.8614 \mathrm{~cm}$ (range 3$11 \mathrm{~cm}$ ). Most were $1.5 \mathrm{~cm}$ in size (19 people, 50\%). There were 11 people who had a tumor size of $1-1.49 \mathrm{~cm}$ $(28.9 \%), 5$ with a size of $0.5-0.99 \mathrm{~cm}(13.2 \%)$, and the remaining 3 with a size of $<0.5 \mathrm{~cm}(7.9 \%)$. Based on histopathological diagnosis, 30 samples were diagnosed as nodular BCC (78,9\%), 4 micronodular BCC (10.5\%), 3 superficial BCC (7.9\%), and 1 pigmented BCC (2.6\%). Then, from this diagnosis, it is determined how the risk of recurrence of the sample is lower or higher. From this study, 34 samples (89.5\%) were found with a lower risk of recurrence, while the remaining 4 samples (10.5\%) were higher.

Table 2. Distribution of BCC sample mean age by sex

\begin{tabular}{|c|c|c|c|c|c|}
\hline Gender & Average & SD & SE & $\mathrm{p}$-value & $\mathrm{N}$ \\
\hline Male & 62,44 & 9,633 & 2,408 & 0,362 & 16 \\
\hline Female & 65,55 & 10,649 & 2,270 & & 22 \\
\hline
\end{tabular}

Based on Table 2, it is found that the mean sample of BCC males is 62.44 years old with a standard deviation of 9.633 years, while the average BCC female sample is 65.55 years old with a standard deviation of 10.649. Statistical test results obtained p value $=0.362$, which indicates at $5 \%$ alpha there is no significant difference in the mean age between the sample of men and women BCC.

Table 3. Correlation of clinicopathological data with histopathological subtype BCC

\begin{tabular}{|c|c|c|c|c|c|c|c|c|c|}
\hline \multirow[t]{2}{*}{ Variabel } & \multicolumn{2}{|c|}{ nodular } & \multicolumn{2}{|c|}{ superficial } & \multicolumn{2}{|c|}{ pigmented } & \multicolumn{2}{|c|}{ micronodular } & \multirow{2}{*}{ value $^{*}$} \\
\hline & $\mathrm{n}$ & $\%$ & $\mathrm{n}$ & $\%$ & $\mathrm{n}$ & $\%$ & $\mathrm{n}$ & $\%$ & \\
\hline Age (years) & & & & & & & & & 0,830 \\
\hline - $21-40$ & 1 & 3,3 & 0 & 0 & 0 & 0 & 0 & 0 & \\
\hline - $41-60$ & 8 & 26,7 & 1 & 33,3 & 1 & 100 & 1 & 25 & \\
\hline - $>60$ & 21 & 70 & 2 & 66,7 & 0 & 0 & 3 & 75 & \\
\hline \multicolumn{10}{|l|}{ Gender } \\
\hline - Male & 14 & 46,7 & 1 & 33,3 & 1 & 100 & 0 & 0 & 0,201 \\
\hline - Female & 16 & 72,7 & 2 & 9,1 & 0 & 0 & 4 & 18,2 & \\
\hline \multicolumn{10}{|l|}{ Work } \\
\hline - Housewife & 8 & 26,7 & 2 & 66,7 & 0 & 0 & 4 & 100 & \\
\hline - Retired & 3 & 10 & 0 & 0 & 0 & 0 & 0 & 0 & 0,157 \\
\hline - Farmer & 8 & 26,7 & 0 & 0 & 1 & 100 & 0 & 0 & \\
\hline - private employees & 11 & 36,7 & 1 & 33,3 & 0 & 0 & 0 & 0 & \\
\hline $\begin{array}{l}\text { Ethnic group } \\
\text { - Aceh } \\
\text { - Batak }\end{array}$ & 3 & $\begin{array}{l}10 \\
20\end{array}$ & $\begin{array}{l}0 \\
0\end{array}$ & $\begin{array}{l}0 \\
0\end{array}$ & $\begin{array}{l}0 \\
1\end{array}$ & $\begin{array}{c}0 \\
100\end{array}$ & $\begin{array}{l}0 \\
1\end{array}$ & $\begin{array}{c}0 \\
25\end{array}$ & \\
\hline
\end{tabular}




\begin{tabular}{lccccccccc} 
- Java & 5 & 16,7 & 1 & 33,3 & 0 & 0 & 1 & 25 & 0,887 \\
- Karo & 11 & 36,7 & 2 & 66,7 & 0 & 0 & 0 & 0 & \\
- Melayu & 3 & 10 & 0 & 0 & 0 & 0 & 1 & 25 & \\
- Nias & 1 & 3,3 & 0 & 0 & 0 & 0 & 0 & 0 & \\
- South Tapanuli & 1 & 3,3 & 0 & 0 & 0 & 0 & 1 & 25 & \\
$\begin{array}{l}\text { Tumor location } \\
\text { - Upper face }\end{array}$ & 1 & 3,3 & 0 & 0 & 0 & 0 & 1 & 25 & \\
- Mid face & 13 & 43,3 & 2 & 66,7 & 1 & 100 & 1 & 25 & \\
- Lower face & 1 & 3,3 & 0 & 0 & 0 & 0 & 0 & 0 & u, rru \\
- Face unknown & 11 & 36,7 & 1 & 33,3 & 0 & 0 & 2 & 50 & \\
- Others & 4 & 13,3 & 0 & 0 & 0 & 0 & 0 & 0 & \\
Tumor Size & & & & & & & & & \\
- $<0,5 \mathrm{~cm}$ & 2 & 6,7 & 0 & 0 & 1 & 100 & 0 & 0 & \\
- $0,5-0,99 \mathrm{~cm}$ & 3 & 10 & 1 & 33,3 & 0 & 0 & 1 & 25 & 0,079 \\
- $1-1,49 \mathrm{~cm}$ & 8 & 26,7 & 1 & 33,3 & 0 & 0 & 2 & 50 & \\
- $\geq 1,5 \mathrm{~cm}$ & 17 & 56,7 & 1 & 33,3 & 0 & 0 & 1 & 25 & \\
\hline & $*$ Pearson chi square test & & & & & & & &
\end{tabular}

Based on Table 3, on occupation, of the 30 nodular BCC samples, there were 11 samples with private employees (36.7\%), 8 housewives (26.7\%), 8 farmers (26.7\%), and 3 retirees. (10\%). All BCC micronodular samples were housewife (100\%). Of the 3 superficial BCC samples, there are 2 housewife $(66.7 \%)$ and the remaining 1 private employee (33.3\%). The only pigmented BCC is farmer (100\%). From the analysis using the Pearson chi square test, it was found that the p-value was 0.157 , which indicates that there is no statistically significant relationship between occupation and BCC histopathological subtypes.

Based on ethnicity in nodular BCC, some of the samples came from the Karo (11 people, 36.7\%), followed by 6 Batak (20\%), 5 Javanese (16.7\%), 3 Acehnese (10\%), 3 Malays (10\%), 1 Nias (3.3\%), and 1 South Tapanuli (3.3\%). Of the 4 micronodular BCCs, there is 1 person each with Batak, Javanese, Malay and South Tapanuli ethnicities (25\%). Of the 3 superficial samples of BCC, there are 2 people with Karo ethnicity $(66.7 \%)$ and 1 Javanese (33.3\%). The only pigmented BCC sample of Batak ethnicity (100\%). From the results of the analysis using the Pearson chi square test, it was found that the p-value was 0.887 , which indicates that there is no statistically significant relationship between ethnicity and BCC histopathological subtypes.

Based on the tumor location, from 30 nodular BCC there were 13 samples located in the mid face $(43.3 \%)$, followed by 11 people on the face with an unknown location (36.7\%), 4 people with an off-face location (13.3\%), 1 person with a location on the upper face (3.3\%), and 1 person with a location on the lower face (3.3\%). Of the 4 samples of micronodular BCC, there were 2 people with tumors on the face whose exact location was unknown (50\%), followed by 1 person in the upper face and mid face (25\% each). Of the 3 superficial BCC samples, there were 2 samples located in the mid face (66.7\%) and 1 in the face of unknown location (33.3\%). The only pigmented BCC sample had a tumor in the mid face (100\%). From the results of the analysis with the Pearson chi square test, it is found that the p-value is 0.880 , which indicates that there is no statistically significant relationship between tumor location and $\mathrm{BCC}$ histopathological subtypes.

Based on tumor size, from 30 nodular BCC there were 17 samples with a size of $1.5 \mathrm{~cm}(56.7 \%)$, followed by 8 people with a size of $1-1.49 \mathrm{~cm}(26.7 \%), 3$ people with a size of $0.5-0.99 \mathrm{~cm}(10 \%)$, and 2 people with a size $<0.5 \mathrm{~cm}(6.7 \%)$. Of the 4 samples of micronodular BCC, there were 2 people with a size of $1-1.49 \mathrm{~cm}(50 \%)$, and 
1 person each with a size of $0.5-0.99 \mathrm{~cm}$ and $1.5 \mathrm{~cm}(25 \%)$. Of the 3 superficial BCC samples, there was 1 sample each with a size of $0.5-0.99 \mathrm{~cm}, 1-1.49 \mathrm{~cm}$, and $1.5 \mathrm{~cm}(33.3 \%)$. The only pigmented BCC sample had a tumor size of $<0.5 \mathrm{~cm}(100 \%)$. From the analysis using the Pearson chi square test, it was found that the p-value was 0.079 , which indicates that there is no statistically significant relationship between tumor size and BCC histopathological subtypes.

Table 4. Relationship of clinicopathological data with risk of BCC recurrence

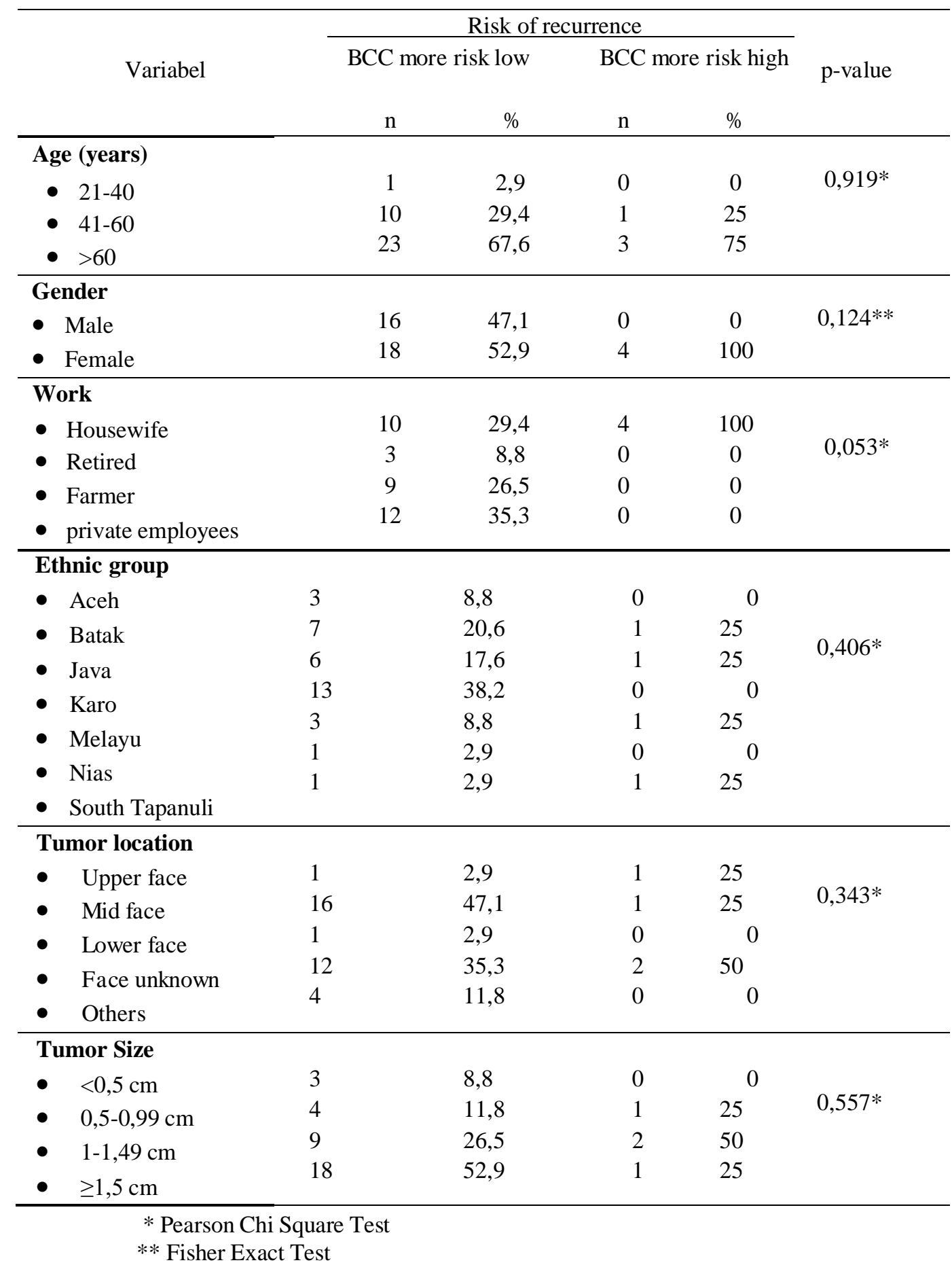


Based on Table 4, on ethnicity, of the 34 samples of the lower risk group for BCC recurrence, there were 13 people from the Karo tribe (38.2\%), followed by 7 Batak people (20.6\%), 6 Javanese (17.6\%), 3 Acehnese $(8.8 \%)$, 3 Melayu (8.8\%), 1 person from Nias (2.9\%), and 1 person from South Tapanuli (2.9\%). Of the 4 groups with a higher risk of BCC recurrence, there is 1 person each with Batak, Javanese, Malay and South Tapanuli ethnicities $(25 \%)$. From the analysis using the Pearson chi square test, it was found that the p-value was 0.406 , which indicates that there is no statistically significant relationship between ethnicity and the risk of BCC recurrence.

Based on tumor location, of the 34 lower risk of BCC recurrence, 16 samples were located in the mid face $(47.1 \%)$, followed by 12 people in the mid face. face with an unknown location $(35.3 \%)$, 4 people with a location outside the face $(11.8 \%), 1$ person with a location on the upper face $(2.9 \%)$, and 1 person with a location on the lower face $(2.9 \%)$. Of the 4 samples of the higher risk group for BCC recurrence, there were 2 people with tumors on the face whose exact location was unknown (50\%), followed by 1 person in the upper face and mid face $(25 \%$ each). From the analysis using the Pearson chi square test, it was found that the p-value was 0.343 , which indicates that there is no statistically significant relationship between tumor location and the risk of BCC recurrence.

Based on tumor size, of the 34 samples of the lower risk group for BCC recurrence, there were 18 samples with a size of $1.5 \mathrm{~cm}(52.9 \%)$, followed by 9 people with a size of $1-1.49 \mathrm{~cm}(26.5 \%), 4$ people with a size of 0.5 $0.99 \mathrm{~cm}(11.8 \%)$, and 3 people with a size $<0.5 \mathrm{~cm}(8.8 \%)$. Of the 4 samples of the risk group for BCC recurrence, there were 2 people with a size of $1-1.49 \mathrm{~cm}(50 \%)$, and 1 person each with a size of $0.5-0.99 \mathrm{~cm}$ and $1.5 \mathrm{~cm}(25 \%)$. From the analysis using the Pearson chi square test, it was found that the p-value was 0.557, which indicates that there is no statistically significant relationship between tumor size and the risk of BCC recurrence.

\section{Discussion}

The number of slides and paraffin blocks from all skin BCC patients who underwent surgery and had been diagnosed histopathologically as BCC that met the inclusion and exclusion criteria at the Anatomic Pathology Unit of H. Adam Malik Hospital Medan in 2018-2020 were 38 samples. BCC is the most common epithelial malignancy in humans $75-80 \%$ of nonmelanoma cancers. ${ }^{1-6} \mathrm{BCC}$ is four to five times more common than squamous cell carcinoma. ${ }^{24}$ Incidence is highest in Australia and lowest in parts of Africa. ${ }^{2}$ Incidence is 40-fold higher in hot climates near the equator, such as Australia. ${ }^{9}$ Worldwide, the incidence of BCC is increasing everywhere except in Australia, which appears to have remained stable. ${ }^{2}$ The incidence of BCC is known to reach 2.75 million cases worldwide annually. ${ }^{7}$ Yahya in 2008 reported $0.11 \%$ and in 2010 was $0.3 \% .{ }^{53}$ Sinaga found that out of 17 cases of skin cancer at Fatmawati Central Hospital, there were only 5 cases of BCC. ${ }^{54}$

BCC most commonly affects people over 40 years of age, although it has been found at a young age. ${ }^{5}$ Most of these carcinomas are found in the sixth and seventh decades of life and are twice as common in men. ${ }^{5,55}$ In this study, Table 1 shows that the mean and standard deviation of sample BCC aged 64.24 \pm 10.218 years (range 3583 years). In addition, it is also known that most of the samples are $>60$ years old (68.4\%), followed by the 41-60 years age group (28.9\%). There is no sample aged $<20$ years. In addition, it is also known that about $57.9 \%$ of the sample are female, while the rest are male (42.1\%). In accordance with the existing literature, BCC often occurs in the elderly, aged between $50-80$ years, with an average of about 65 years. ${ }^{1,4,11,12}$ Increasing age will increase the risk of cumulative UV exposure and decrease the capacity and ability to repair DNA damage. ${ }^{19}$ The reduced density of skin melanocytes in the elderly also leads to more extension of UV penetration into the dermis causing more extensive damage. ${ }^{56}$ Therefore, increasing age may increase the risk of non-melanoma skin cancer.

The incidence of $\mathrm{BCC}$ was found to be 5 times higher in those aged over 75 years than in those aged 50-55 years. $^{19}$

Similar to the research in Makassar and Padang, this research also reported that BCC was more common in women than men. ${ }^{57,58}$ These two studies contradict the existing theory. Usually, men are more prone to suffer from $\mathrm{BCC}$ because they are more likely to smoke and work outdoors so that they are more often exposed to UV rays. These factors are thought to trigger tumor growth The difference in the results in this study may be due to the fact that many women in Medan are already working outside, thereby increasing the risk factors for the development of BCC.

From the results of this study, it was found that about $36.8 \%$ of the sample were householders, $31.6 \%$ private employees, $23.7 \%$ farmers, and $7.9 \%$ retirees. Based on ethnicity, around $34.2 \%$ of the sample was Karo, followed by $21.1 \%$ Batak, $18.4 \%$ Javanese, 10.5\% Melayu, 7.9\% Acehnese, 5.3\% South Tapanuli and 2. 6\% Nias. The results of this study are not in line with other studies. ${ }^{19,55}$ Toha et al in their study found that about $26.2 \%$ of their research subjects had farmer jobs. This is consistent with a study in Poland which reported that farmers are at greater risk of suffering from BCC, so education is needed to minimize the risk. ${ }^{55}$ In this study, there were more housewife where they were less likely to be exposed to the sun than farmers. Domestic workers tend to spend more time in the kitchen and less time in the sun. In the kitchen, they are constantly exposed to the heat and smoke produced during cooking. ${ }^{14}$ Research in Turkey showed that BCC occurred earlier in indoor workers (intermittent UV exposure) than in outdoor workers (chronic UV exposure). ${ }^{60}$

The risk of developing BCC is influenced by environmental and individual factors. These factors will interact through several series of events over a long period of time in a cell. The pathogenesis of this carcinoma involves 
exposure to UV light which induces mutations in tumor suppressor genes. ${ }^{5}$ In addition to UVA and UVB rays, which have been shown to be carcinogenic factors, UVC rays filtered by the ozone layer have a large oncogenic capacity. The ozone layer is being destroyed every day. It is estimated that there is an increase in the incidence of skin cancer by 2 to $4 \%$ for every $1 \%$ reduction in the ozone layer. ${ }^{59}$ Depletion of the ozone layer in recent decades has shown an increase in UV radiation. ${ }^{61} \mathrm{UV}$ exposure depends on the time, pattern and amount of UV radiation, but until recently However, the relationship between BCC risk and UV exposure has not yet been clearly elucidated. Physical factors can affect the ability to respond to UV radiation, such as skin, hair and eye color. Although most BCCs are located in areas that are frequently exposed to the sun, some cases of BCC also occur in areas of the body that are not exposed to sunlight. This may explain other risk factors in the pathogenesis of BCC. ${ }^{5}$ Chemical carcinogens such as arsenic, coal tar products, psoralen, ionized radiation, fiberglass powder and drycleaning agents can increase the risk of non-melanoma skin cancer. This is determined by the potential for carcinogens, duration of exposure and the completeness of protective equipment used by workers in the industrial sector. Smoking is also one of the factors that influence the incidence of BCC. Several phenotypic characteristics can distinguish individual susceptibility to $\mathrm{BCC}$, namely hair color, skin color, and ability to tanning. Other predisposing factors include a history of xeroderma pigmentosum, nevoid BCC syndrome and a family history of skin cancer.

Anatomical locations are divided based on Baker's (2007) classification which divides facial predilection into 3 groups, namely the upper face (upper face), mid face (middle face and ears), and lower face (lower face). This classification differs anatomically according to the structure of the thickness of the epidermis, the content of the adnexal or appendix skin, and the physiological function of the pilosebaceous unit.

In this study, most of the carcinomas were found in the mid face (44.7\%), consisting of $15.8 \%$ eyelids, $10.5 \%$ eyes, $7.9 \%$ nose, $5.3 \%$ cheek, $2.6 \%$ periorbita, and $2.6 \%$ ear. There were about $5.3 \%$ of the samples had carcinoma on the upper face and only $2.6 \%$ in the lower face (lips). The results of this study are in line with the research of Toha et al. They also found that the most common location was in the midface area $(68.4 \%)$; where the most common in the nasal region (42.1\%), around the eyes (15.8\%), and cheeks $(10.5 \%) .{ }^{19}$ This is because BCC in the midface region is prone to perineural spread with high recurrence compared to other places. ${ }^{62}$ In this study, the most common location was the eyelids. The eyelids are a fairly narrow surface area but include areas of skin that are often exposed to sunlight. The thin layer of skin on the eyelids makes the eyelids sensitive to irritants and ultraviolet light. Therefore, the lids are a major risk factor for the development of BCC. ${ }^{59}$

In addition, in this study, it was found that about $36.8 \%$ of the samples were found in the facial area, but the location was not known more clearly. Apart from the face, BCC samples can be found in other areas such as the neck $(10.6 \%)$. In accordance with what Susilorini et al found in their research, the most common location for skin malignancies was the face area (43.6\%), followed by the head $(32.5 \%)$ and lower extremities $(11.6 \%)$. This may be due to frequent sun exposure on the face area rather than the head and neck. ${ }^{63}$

This tumor predilection is critical for the spread of BCC. Tumors in the ala nasi region may spread asymptomatically to the perichondria. The periorbital region (canthus) may spread around the ethmoid sinus, resulting in enucleation and death, whereas spread over the tarsal plate involving the conjunctival mucosa may increase eyelid recurrence. The preauricular region especially the tragus is an important embryonic fusion area, if there is perichondral extension then the tumor will be difficult to trace, while the postauricular sulcus is an embryonic fusion plane where the tumor often grows aggressively. In the scalp region there can be deep invasion and expansion of the tumor along the periosteal plate, after the calvarium is penetrated the BCC can expand and involve the dura mater.

The primary size of the BCC may play a role in its metastatic potential. In this study, it was found that the mean and standard deviation of the sample had a size of $1.789 \pm 1.8614 \mathrm{~cm}$ (range $0.3-11 \mathrm{~cm}$ ). About $50 \%$ of the samples had a size of $1.5 \mathrm{~cm}, 28.9 \%$ with a size of $1-1.49 \mathrm{~cm}, 13.2 \%$ with a size of $0.5-0.99 \mathrm{~cm}$, and the rest with a size of $<0.5 \mathrm{~cm}$. Similar results were found by Wibawa et al, who found that the mean diameter of BCC lesions was $2 \mathrm{~cm}$ (range $0.2-15 \mathrm{~cm}$ ). ${ }^{64}$ The results of this study are not in line with Bariani et al. They found that about $58.9 \%$ of BCCs were $0.6-1.5 \mathrm{~cm}$ in size, $30.4 \%$ were $0.5 \mathrm{~cm}$ in size, and the remainder were $>1.5 \mathrm{~cm} .61$ Recurrence rate approximately $2 \%$ for all $\mathrm{BCCs}$ (primary and recurrent) less than $2 \mathrm{~cm}$ in diameter and increases to close to $8 \%$ for BCCs greater than $5 \mathrm{~cm} .{ }^{19}$

The study also found that about $78.9 \%$ of the sample were diagnosed as nodular BCC, $10.5 \%$ micronodular BCC, $7.9 \%$ superficial BCC, and $2.6 \%$ pigmented BCC. Then, from this diagnosis, it is determined how the risk of recurrence of the sample is lower or higher. From this study, 34 samples $(89.5 \%)$ were found with a lower risk of recurrence, while the remaining 4 samples $(10.5 \%)$ were higher. Similar results were also obtained by Yahya et al, where the most common subtype found was nodular BCC and the second most common was pigmented BCC. ${ }^{53}$ In this study, it was also found that the average BCC male sample was 62.44 years old with a standard deviation of 9.633 years, while the average BCC female sample was 65.55 years old with a standard deviation of 10.649. Statistical test results obtained $\mathrm{p}$ value $=0.362$, which indicates at $5 \%$ alpha there is no significant difference in the mean age between the samples of BCC males and females. However, this result is in contrast to Al-Qarqaz et al who found that there was a significant difference between the mean age and sex of BCC sufferers 
$(\mathrm{p}=0.018)$. in women, while age $>60$ years is more common in men. ${ }^{65}$ In addition, this study also found no statistically significant relationship between occupation and ethnicity with the histopathological subtype of BCC (with p-values of 0.157 and 0.887 , respectively).

From the results of this study, only 1 person was found in nodular BCC aged 20-40 years (3.3\%). The four subtypes all have samples those aged $>60$ years and 41-60 years with different percentages. From the analysis using the Pearson chi square test, it was found that there was no statistically significant relationship between age and BCC histopathological subtypes (p value 0.830) (Table 3). As Rivers et al found, the nodular BCC subtype tends to occur at a younger age (0-19 years).66 According to the literature, superficial BCC tends to occur in younger patients than the other subtypes. ${ }^{67}$ However, this is contradictory. behind this study and Rivers et al.

From the results of this study, it can be seen that in both nodular BCC, superficial BCC, and micronodular BCC, more women suffer from these subtypes than men $(72.7 \%, 9.1 \%$ and $18.2 \%$, respectively). The only sample of pigmented $\mathrm{BCC}$ was male (100\%). However, after analyzing the Pearson chi square test, it was found that there was no statistically significant relationship between gender and BCC histopathological subtypes ( $\mathrm{p}$ value $=0.201$ ). Raasch et al also found that superficial BCC was more common in women, as in this study. ${ }^{68}$ However, Rivers et al found that nodular BCC was more common in men, which contradicts this study. ${ }^{66}$

This study showed that the subtypes of nodular BCC, superficial BCC, pigmented BCC and micronodular $\mathrm{BCC}$ were all found most frequently on the face, especially the mid face. However, from the results of the Pearson chi square test analysis, no statistically significant relationship was found between tumor location and BCC histopathological subtypes (p-value 0.880). According to Marzuka and Book and Rivers et al, nodular and micronodular BCC are found mainly on the face, particularly the cheeks, nasolabial folds, forehead, neck and eyelid. However, in contrast to superficial BCC, this subtype occurs more frequently on the trunk and extremities than the other subtypes. ${ }^{66,67}$ This study instead found more samples of BCC on the face. In addition, it was also found that nodular BCC, micronodular BCC, and superficial BCC tend to be large. However, from the analysis using the Pearson Chi Square Test, it was found that there was no statistically significant relationship between tumor size and BCC histopathological subtype (p-value 0.079).

This study found that there was no statistically significant relationship between age, gender, occupation, ethnicity, tumor location, and tumor size with the risk of BCC recurrence (with p-values of 0.919; 0.124; 0.053; 0.406; 0.343; and 0.557, respectively). Similar results were also found by Toha et al. They divided BCC into nonaggressive (BCC NA) and aggressive (BCC A) based on histopathology. Then, they correlated the demographic and clinicopathological data with the BCC classification. The results of this study indicate that more women suffer from BCC A than BCC NA. The age of the patients ranged from 40-75 years (mean $57.5 \pm 17.5$ years), where most of them were over 50 years old, which was around $84.2 \%$. Main occupation is farmer. The most common tumor predilection was in the mid face (64.8\%) which consisted of BCC A (57.9\%) and BCC NA (10.5\%) groups. Based on its aggressiveness, BCC A was more commonly found in the mid face region than other areas. Walling's criteria stated that the size of the lesion (diameter $>2.5-3.0 \mathrm{~cm}$ ) was associated with BCC A. ${ }^{19}$ Meanwhile, based on tumor diameter, most were $>2 \mathrm{~cm}$ in the BCC A $(47.4 \%)$ and BCC NA groups $(5,3 \%)$. However, the results of statistical tests do not show any relationship between demographic and clinicopathological data with BCC A and BCC NA in the study of Toha et al. ${ }^{19}$

Research in Makassar showed that BCC A was $91.9 \%$ and BCC NA was $8.1 \%$ with the micronodular subtype being the most common. ${ }^{57}$

Research in Palembang found that BCC NA was $74.1 \%$ with the most nodular subtypes and BCC A was $25.9 \%$ with the most superficial subtypes.53 The existence of these different results requires further research.

Unfortunately, there are some limitations in this study, namely as follows. First, clinical data written by clinicians and recorded in medical records is incomplete. For example, many BCC samples do not know the exact location of the carcinoma lesion (only written on the face but do not know which part of the face). Though the location of predilection is very important in determining the prognosis. Second, it is unfortunate that the results of the dermoscopic examination were not recorded in the medical record section so that it could not add to this research variable and could not be investigated further. Third, the lack of data regarding whether they are often exposed to the sun, how long they are exposed to and whether the BCC sample uses sunblock and so on.

During this research, there were difficulties experienced by researchers in the form of difficulty in obtaining medical record data due to the lack of information written by clinicians and not recorded in online medical records.

\section{Conclusion}

After conducting research on samples of basal cell carcinoma in the skin at the Anatomic Pathology Unit, $\mathrm{H}$. Adam Malik Hospital, Medan, the following conclusions can be drawn:

a) Approximately $68.4 \%$ of the sample are $>60$ years old; $57.9 \%$ are female; $36.8 \%$ housewives; $44.7 \%$ located in the mid face with the most locations on the eyelids; $50 \%$ have a size of $1.5 \mathrm{~cm} ; 78.9 \%$ were diagnosed with nodular BCC; and $89.5 \%$ lower risk of recurrence.

b) At $5 \%$ alpha, there is no significant difference in the mean age between BCC male and female samples.

c) There was no statistically significant relationship between age, sex, occupation, ethnicity, tumor location, and 
tumor size with BCC histopathological subtypes.

d) There was no statistically significant relationship between age, gender, occupation, ethnicity, tumor location, and tumor size with the risk of BCC recurrence.

\section{Acknowledgment}

We would acknowledge to all staf and resident of Anatomical Pathology Department of Universitas Sumatera Utara and H. Adam Malik hospital, Medan, Indonesia for their help and cooperation.

\section{Ethical Approval}

Health Research Ethical Committee, Universitas Sumatera Utara, Medan, Indonesia approved this study.

\section{References}

1. Tan ST, Ghaznawie M, Reginata G. Deteksi Dini Karsinoma Sel Basal. Indonesian Journal of Cancer. 2016;10(2):61-6.

2. Messina J, Epstein EH, Kossard S, McKenzie C, Patel RM, Patterson JW, et al. Basal Cell Carcinoma. In: Elder DE, Massi D, Scolyer RA, Willemze R (eds.).WHO Classification of Skin Tumours, $4^{\text {th }}$ edition. Lyon: IARC; 2018. P.26-34.

3. Lazar AJ. Chapter 25 The Skin. In: Kumar V, Abbas AK, Aster JC. Robbins \& Cotran Pathologic Basis of Disease. Canada: Elsevier; 2021. P1147-9.

4. Kirkham N and Aljefri K. Chapter 29 Tumors and Cysts of the Epidermis. In: Elder DE. Lever's Histopathology of the Skin, $11^{\text {th }}$ edition. China; Wolters Kluwer; 2015. P1945-76.

5. Miryana W, Reza NR, Sarwono I, Cholis M. Gambaran Histopatologi Karsinoma Sel Basal. MDVI. 2013;40(3):138-44.

6. Qui NV and Ngoc PN. Study on Clinical, Histopathological Features and Evaluation Results of Skin Cancer Treatment in Can Tho Oncology Hospital. Jurnal Kesehatan Masyarakat Nasional. 2016 Februari;10(3): 104-6.

7. Dewi MKA, Istiadi H, Wijaya I. Ekspresi CD10 dan PAS (Periodic Acid Schiff)pada Basal Cell Carcinoma di RSUP Dr. Kariadi Semarang. Media Me Muda. 2017 Sept-Dec;2(3):191-6.

8. Omland SH, Wettergren EE, Mourier T, Hansen AJ, Aplund M, Mollerup S, etal. Cancer Associated Fibroblasts (CAFs) are Activated in Cutaneous BaslCellCarcinoma and in the Peritumoral Skin. BMC Cancer. 2017;17:675.

9. Kumar V, Abbas AK, Aster JC. Chapter 24 Skin. In: Robbins Basic Pathology,Tenth Edition. Canada: Elsevier; 2018. P902.

10. Verkouteren JAC, Ramdas KHR, Wakkee M, Nijsten T. Epidemiology of BasalCell Carcinoma: Scholarly Review. Br J Dermatol. 2017 Aug;177(2):359-72.

11. Yelitha S, Agus S, Yenny SW. Hubungan Ekspresi Ki-67 dan Tipe Stroma Peritumoral dengan Varian Histopatologik Karsinoma Sel Basal. Majalah Patologi. 2018 Mei;27(2):30-7.

12. Chinem Vp and Miot HA. Epidemiology of Basal Cell Carcinoma. An Bras Dermatol. 2011;86(2):292-305.

13. Fakhrosa I, Sutedja EK, Agusni JH, Feriza V, Saraswati NA. Tinjauan Pustaka:Manifestasi Klinis dan Gambaran Dermoskopi pada Karsinoma Sel Basal. Syifa’ Medika. Maret 2018;8(2):54-67.

14. George RM, Nazeer M, Criton S, Abraham UM, Francis A. ClinicopathologicalAnalysis of Basal Cell Carcinoma- A Retrospective Study. JSSTD. Jan-June 2021;3(1):51-5.

15. Al-Qarqaz F, Bodoor K, Al-Tarawneh A, Eloqayli H, Al Gargaz W, Alshiyab D, et al. Basal Cell Carcinoma Pathology Requests and Reports are Lacking Important Information. Journal of Skin Cancer. 2019, Article ID 4876309. doi:10.1155/2019/4876309.

16. Betekhtin M, Ananiev J, Tchernev G, Zisova L, Philipov S, Hristova R. Early Onset Basal Cell Carcinoma: Surgical Approach. Acta Medica Bulgarica. 2014;XLI (1): 82-7.

17. Saldanha P, Shantala PR, Upadhaya K. Cutaneous Basal Cell Carcinoma: A Morphological Spectrum. Archives of Medicine and Health Sciences. 2015 Jan-Jun;3(1):24-8.

18. Al-Qarqaz F, Marji M, Bodoor K, Almomani R, Al Gargaz W, Alshiyab D, Muhaidat J, et al. Clinical and Demographic Features of Basal Cell Carcinomain North Jordan. Hindawi Journal of Skin Cancer. 2018, Article ID 2624054. doi: 10.1155/2018/2624054

19. Toha SS, Rahman A, Mochtar M, Julianto I, Dharmawan N, Mawardi P, WasitaB, et al. Kejadian Karsinoma Sel Basal di RSUD Dr. Moewardi Surakarta berdasarkan Subtipe Histopatologi menurut Jenis Kelamin, Usia, Lokasi Anatomi, dan Diameter Tumor. CDK-275. 2019;46(4):256-60.

20. Mescher AL. Chapter 18 Skin. In: Junguira's Basic Histology, Fourteenth Edition. United States: McGraw-Hill Education; 2016. P37181.

21. Gartner LP. Chapter 11 Integument. In: Color Atlas and Text of Histology, Seventh Edition. China: Wolters Kluwer; 2018. P834-8.

22. Kuehnel W. Integumentary System, Skin. In: Color Atlas of Cytology, Histology and Microscopy Anatomy, $4^{\text {th }}$ edition. Germany: Thieme; 2003. P438-43.

23. Kierszenbaum AL and Tres LL. Chapter 11 Integumentary System. In: Histology and Cell Biology, An Introduction to Pathology, fifth edition. Canada: Elsevier; 2020. P390-401.

24. Van De Graaf KM. Chapter 5 Integumentary System. In: Van De Graaf: HumanAnatomy, Sixth Edition. United States of America: The McGraw-Hill Companies; 2001. P105-12.

25. Sontakke Y. Chapter 14 Skin and Its Appendages. In: Textbook of Human Histology with Color Atlas, 3D Illustrations and Flowcharts. New Delhi: CBS Publishers \& Distributors Pvt Ltd; 2020. P150-7.

26. McGrath JA. Chapter 1 The Structure and Function of Skin. In: Calonje E, Brenn T, Lazar A. McKee's Pathology of the Skin with Clinical Correlations. China: Elsevier Saunders; 2012. P1.

27. Calonje E, Brenn T, Lazar A. Chapter 24 Tumors of The Surface Epithelium. In: McKee's Pathology of the Skin with Clinical Correlations. China: Elsevier Saunders; 2012. P1088-100.

28. Kim DP, Kus KJB, Ruiz E. Basal Cell Carcinoma Review. Hematol Oncol ClinN Am. 2019;33:13-24. doi: 10.1016/j.hoc.2018.09.004.

29. Dika E, Scarfi F, Ferracin M, Broseghini E, Marcelli E, Bortolani B, et al. BasalCell Carcinoma: A Comprehensive Review. Int J Mol Sci. 2020;21:5572. doi:10.3390ijms21155572.

30. Frankel A and Goldenberg G. Presentations and Treatment of Basal Cell Carcinoma: A Review. Cutaneous Oncology Today. 2011 Oct:19.

31. Tang JY, Epstein EH, Oro AE. Chapter 111 Basal Cell Carcinoma and Basal Cell Nevus Syndrome. In: Kang S, Amagai M, Bruckner AL, Enk AH, Margolis DJ, McMichael AJ, et al (eds.). Fitzpatrick's Dermatology, $9^{\text {th }}$ Edition, Volume 2. United States: McGraw-Hill Education; 2019. P1884-91. 
32. Calonje E, Brenn T, Lazar AJ, Billings SD. Chapter 24 Tumors of the Surface Epithelium. In: McKee's Pathologyofthe Skin with Clinical Correlations, fifthedition. China: Elsevier; 2020. P1170-86.

33. Marghoob AA, Usatin e RP, Jaimes N. Dermoscopy for the Family Physician. Am Fam Physician.2013;88(7):441-50.

34. Nischal KC and Khopkar U. Dermoscope. Indian J Dermatol Venereol Leprol. 2005 Jul-Aug;71(4):300-4.

35. Nirmal B. Dermatoscopy: Physics and Principles. Indian J Dermatopathol Diagn Dermatol. 2017;4:27-30.

36. Conforti C, Giuffrida R, Vezzoni R, Resende FSS, Meo N, Zalaudek I. Dermoscopy and The Experienced Clinicians. International Journal of Dermatology. 2019. doi:10.1111/ijd.14512.

37. Yelamos O, Braun RP, Liopyris K, Wolner ZJ, Kerl K, Gerami P, et al. Usefulness of Dermoscopy to Improve the Clinical and Histopathologic Diagnosis of Skin Cancers. J Am Acad Dermatol. 2019Feb;80:365-77. doi:10.1016/jaad.2018.07.072.

38. Cabrijan L, Lipozencic J, Batinac T, Lenkovic M, Gruber F, Zgombic ZS. Correlation Between Clinical-Dermatoscopic and Histopathologic Diagnosis ofSkin Tumors in Our Patients. Coll Antropol. 2008;32(2):195-7.

39. Stephen K and Fleming C. An Introduction to Dermoscopy. Dermatological Nursing. 2013;12(4):20-8.

40. Braun RP, Scope A, Marghoob AA, Kerl K, Rabinovitz HS, Malvehy J.Chapter 3 Histopathologic Tissue Correlations of Dermoscopic Structures.In: Marghoob AA, Malvehy J, Braun RP (eds.). Atlas of Dermoscopy, Second Edition. United Kingdom: Informa Healthcare; 2012. P10-25; 29-30.

41. Betekhtin M, Ananiev J, Tchernev G, Zisova L, Philipov S, Hristova R. Early Onset Basal Cell Carcinoma: Surgical Approach. Acta Medica Bulgarica. 2014;XLI (1): 82-7.

42. Yelamos O, Braun RP, Liopyris K, Wolner ZJ, Kerl K, Gerami P, et al. Usefulness of Dermoscopy to Improve the Clinical and Histopathologic Diagnosis of Skin Cancers. J Am Acad Dermatol. 2019 Feb;80:365-77.

43. Boyd AS. Chapter 26 Tumors of the Epidermis. In: Barnhill RL. Barnhill's Dermatopathology, Fourth Edition. United States: McGrawHill Education; 2020. P740-51.

44. Sangueza OP, Tuchayi SM, Mansoori P, Aldawsari SA, Al-Dabagh A, Fathaddin AA, et al. Tumors of the Epidermis. In: Dermatopathology Primer of Cutaneous Tumors. Boca Raton: CRC Press; 2016. P18-9.

45. Prieto VG, Shea CR, Celebi JT, Busam KJ. Chapter 11 Adnexal Tumor. In: Busam KJ (ed.). Dermatopathology. United States of America: Saunders Elsevier; 2010. P389-97.

46. Patterson JW. Chapter 32 Tumors of the Epidermis. In: Weedon's Skin Pathology, Fifth Edition. China: Elsevier; 2021. P848-58.

47. Cameron MC, Lee E, Hibler B, Barker CA, Mori S, Cordova M, et al. Basal Cell Carcinoma: Part 1. Journal of the American Academy of Dermatology. 2018. doi: 10.1016/j.jaad.2018.03.060.

48. Arisanty R dan Tanurahardja B. Profil Keganasan Primer Kulit Tersering di Departemen Patologi Anatomik Rumah Sakit Cipto Mangunkusumo Tahun 2005-2009. Majalah Patologi. 2011;20(1):14-20.

49. Kamus Besar Bahasa Indonesia. Usia [Internet]. Jakarta: Badan Pembinaan danPengembangan Bahasa Kementerian Pendidikan dan Kebudayaan; 2021 [cited2021 March 24]. Available from: http://kbbi.web.id.

50. Emiroglu N, Kemeriz F, Cengiz FP. The Relation between Dermoscopy and Histopathology of Basal Cell Carcinoma. An Bras Dermatol. 2015;90(3):351- 6 .

51. Kamus Besar Bahasa Indonesia. Pekerjaan [Internet]. Jakarta: Badan Pembinaan dan Pengembangan Bahasa Kementerian Pendidikan dan Kebudayaan; 2021 [cited 2021 Sep 24]. Available from: http://kbbi.web.id.

52. Kamus Besar Bahasa Indonesia. Suku [Internet]. Jakarta: Badan Pembinaan danPengembangan Bahasa Kementerian Pendidikan dan Kebudayaan; 2017 [cited2021 Sep 24]. Available from: http://kbbi.web.id.

53. Yahya YF, Krishnaputri S, Harianti T, Torual TL, Fantoni Y, Kasim BI. Profil Karsinoma Sel Basal Primer di RSUP M. Hoesin Palembang. MDVI. 2011;38(2):78-83.

54. Sinaga D. The Evaluation of Skin Cancer Profile in Fatmawati Hospital Centre. Journal of Education and Practice. 2018;9(4):1-8. ISSN2222288X.

55. Szewczyk M, Pazdrowski J, Golusinski P, Danczak-Pazdrowska A, ŁuczewskiŁ, Marszałek S. Basal Cell Carcinoma In Farmers: An Occupation Group At High Risk.Int Arch Occup Environ Health. 2016;89:497-501.

56. Syrigos KN, Tzannou I, Katirtzoglou N, Georgiou E. Skin cancer in the elderly.in vivo. 2005;19(3):643-52

57. Marcelina P, Mappiasse A, Anwar AI, Ganda IJ, Hatta M, Masadah R. Expression of patched-1 protein in aggressive and nonaggressive basal cell carcinoma. Am J Clin Exp Med. 2016;4(5):122-8

58. Wilvestra S, Lestari S, Asri E. Studi Retrospektif Kanker Kulit di Poliklinik Ilmu Kesehatan Kulit dan Kelamin RS Dr. M. Djamil Padang Periode Tahun 2015-2017. Jurnal Kesehatan Andalas. 2018;7(Supplement 3):47-49.

59. Sari YP, Yuliawati P, Djelantik AAAS, Utari NML, Triningrat AAMP, Manuaba IBP. Karakteristik dan Keakuratan Diagnosis Klinis terhadap Hasil Patologi Anatomi Tumor Palpebra di Rumah Sakit Umum Pusat SanglahDenpasar Periode 1 Januari 2015 - 31 Desember 2016. Medicina. 2018;49(1):78-83.

60. Dogan G. Basal Cell Carcinoma in Outdoor versus Indoor Workers in Turkey. International Journal of Dermatology. 2007;46:43-6.

61. Bariani RL, Nahas FX, Barbosa MVJ, Farah AB, Ferreira LM. Basal Cell Carcinoma: An Updated Epidemiological and Therapeutically Profile of An Urban Population. Acta Cirurgica Brasileira. 2006;21(2):66-73.

62. Mawardi P, Kalim H, Kalim KH, Fitri LE, Mintaroem K, Mudigdo A, et al. Mid-face location of primary basal cell carcinoma related to canceraggressivity. Asian Pac J Trop Dis. 2016;6(8):650-3.

63. Susilorini, Sadhana U, Widjaya I. Pattern and Frequency of Skin Malignanciesat Laboratory of Pathology Anatomy Dr. Kariadi General Hospital in 2008- 2009. Sains Medika. Januari-Juni 2015;6(1):21-24.

64. Wibawa LP, Andardewi MF, Krisanti IA, Arisanty R. The Epidemiology of Skin Cancer at Dr. Cipto Mangunkusumo National Central General Hospital from 2014 to 2017. J Gen Proced Dermatol Venereol Indones. 2019;4(1):11-6.

65. Callens J, Eycken LV, Henau K, Garmyn M. Epidemiology of Basal and Squamous Cell Carcinoma in Belgium: The Need for a Uniform and Compulsory Registration. JEADV. 2016. doi: 10.1111/jdv.13703.

66. Rivers JK, Mistry BD, Hung T, Vostretsova K, Mistry N. A 13-year retrospective study of basal cell carcinoma in a Canadian dermatology practiceA comparison between anatomical location and histopathologic subtypes. J Cutan Med Surg. 2016;20(3):233-40.

67. Marzuka A, Book S. Basalcell carcinoma: Pathogenesis, epidemiology, clinicalfeatures, diagnosis, histopathology, and management. Yale J Biol Med. 2015;88(2):167-79 Raasch BA, Buettner PG, Garbe C. Basal cell carcinoma: histological classification and body-site distribution. Br J Dermatol.2006;155(2):401-407.

68. Raasch BA, Buettner PG, Garbe C. Basal cell carcinoma: histological classification and body-site distribution. Br J Dermatol.2006;155(2):401-407 